
high dam, pp. 1054 - 1077

\title{
PERFORMANCE STUDY OF GENERATOR AIR COOLERS FOR THE HYDRO-POWER PLANT AT ASWAN HIGH DAM
}

\author{
A. Kahoul ${ }^{1}$, H. M. Shafey ${ }^{2,}$, A. K. Abdel-Rahman ${ }^{3}$ \\ ${ }^{1}$ Hydro-Power Generation Company, Aswan, Egypt \\ ${ }^{2}$ Mechanical Eng. Dept., Faculty of Engineering, Assiut University, Assiut, Egypt
}

Received 10 March 2013 , accepted 11 April 2013

\begin{abstract}
This paper presents a comparative experimental study on the performance characteristics of the circulating air coolers for the generators of the hydro-power plant of the High Dam in Aswan. The study considers two different air-water cooler designs of cross flow finned tubes heat exchangers working under varying operating conditions. The circulating air temperatures and the cooling water pressures for twelve coolers in each of the twelve units of the hydro-power plant were measured and analyzed to obtain useful results describing the cooler performance. The experimental results are based on measurements over total time duration of 1008 operating hours covering 42 summer days. The results are discussed to investigate the effects of time variation of the generated power, and the locations of the coolers and the power units on the performance of both cooler designs. The results of the actual fouling factor indicate that both coolers were designed with excess surface area to work well for long periods. The agreement of the experimental results with the commonly used effectiveness empirical relation indicates the proper performance of the working coolers. On the other hand, the discussion of the results showed the malfunction of some coolers due to the blockage of their damaged tubes. The overall performance of the air coolers in most power units of the plant maintains good flow behaviour of the hot air and uniformity of its temperature at levels sufficiently below the normal design temperature range for the generators of most power units.
\end{abstract}

Keywords: Hydro-power generators, Air-water coolers, Cross flow heat exchangers, Performance characteristics, and Fouling factor

\section{Introduction}

Studies of the cooling air in generators are of great importance especially in hydro-power generators. Sufficient and correct cooling in generators results in longer lifetimes of certain components such as insulation. Furthermore, the electric resistances of the coils and the windings are temperature dependent. This means that in order to keep the generator at its highest efficiency, it should work in its normal design temperature range $\left(60^{\circ} \mathrm{C}-80^{\circ} \mathrm{C}\right)$ [1]. A hydro-power generator has a closed circuit for cooling air with radial-axial flow. In this circuit the hot air exiting from the stator, is re-cooled by air-water heat exchangers (air coolers). The performance of these air coolers greatly affects the thermal behavior of the cooling air. Most of the previous studies have been concerned with flow characteristics of the cooling air. Computational and experimental investigations were performed on cooling air flow behavior in generators [1-5]. However, the performance characteristics of the air coolers have not yet received sufficient attention of the research work. The present research work deals with the performance characteristics of the air

\footnotetext{
* Corresponding author.

Tel.: +20882411135

E-mail address: hamdy.shafei@eng.au.edu.eg
} 
coolers used with the generators of the hydro-power plant in Aswan High Dam located on the River Nile. The plant is located in the north side of the dam 20 kilometers south of Aswan town in Upper Egypt. The power plant having 12 generators, was installed and operated in 1967. Each generator originally produces a rated power of $175 \mathrm{MW}$ and is cooled by twelve air coolers. Since the installation of the plant, the original air coolers included in the cooling air circuit of the original generators, were able to satisfy the required normal temperature range. However, some problems have been experienced with the original air coolers and showed that they are strongly affecting their performance. When replacing generators in 2005 by new ones of increased rated power (200 MW each), it was found that some tubes of the original coolers were exposed to damage due to corrosion and erosion. Investigating the coolers with damaged tubes, it was concluded that the tubes of the remainder coolers were also expected to be damaged within few months in the near future. Also, the increase in generated power is liable to produce more thermal energy added to the load of the original coolers with damaged tubes. Accordingly, it was decided to gradually replace all the original coolers with so-called new coolers of different design. The erected new coolers have not satisfied the required generators temperature conditions within the first year of its operation. Consequently, in 2006, the authority of the hydro-power plant has planned to investigate the working coolers, both the erected new coolers and the existing original coolers. The goal of the investigation planned by authority has been to decide upon the required modification of the new coolers for satisfactory temperature conditions of the new generators. It was convenient to support the authority of the hydro-power plant in its planned investigation with a detailed study for the performance of the working air coolers. Such a study should be based on the fundamentals, correlations, and standard experimental procedure in the field of heat exchangers. Previous studies [6-10] dealt with heat exchangers similar to the working air coolers.

This paper presents detailed comparative experimental study on the performance evaluation for the working air coolers of the Aswan High Dam hydro-power generators. The study is carried out under varying operating conditions associated with time variation of the generated power and with the locations of the air-water coolers and power units with respect to the dam. The paper adds more knowledge on the thermal behavior of the generator cooling and the performance of the air coolers. Measurements of air temperatures and cooling water pressures together with the records of the generated power were monitored and analyzed to investigate the performance characteristics of the original and new air coolers.

\section{Overview of the hydro-power plant}

Figure 1 shows a sectional view illustrating the main features of Aswan High Dam and its hydro-power plant. The second manmade artificial Lake Nasser is formed in front of the dam. The lake is 500 kilometers long and 10 kilometers wide. The highest level of stored water in Lake Nasser is 178 meters behind the dam. Six tunnels were constructed through the dam body to provide intake of water for power and generators cooling. Each tunnel with a diameter 15 meters and a length of 282 meters ends with two Francis hydraulic turbines and two spillways. The maximum allowable downstream level is 111.5 meters.

Journal of Engineering Sciences, Assiut University, Faculty of Engineering, Vol. 41, No. 3, May, 2013,E-mail address: jes@aun.edu.eg 
A. Kahoul et al., Performance study of generator air coolers for the hydro-power plant at Aswan high dam, pp. 1054 - 1077

Figure 2 shows a sectional model of one of the hydro-power units consisting of a Francis hydraulic turbine coupled to its generator. The turbine weighs 140 tons and rotates at constant speed $100 \mathrm{rpm}$, with $175 \mathrm{MW}$ (original) and $200 \mathrm{MW}$ (new) output power. The generator is surrounded by cylindrical frame within which twelve cross flow air-water coolers are installed. Each cooler consists of two identical tube-bundles inserted in one of the double-opening windows of the frame.

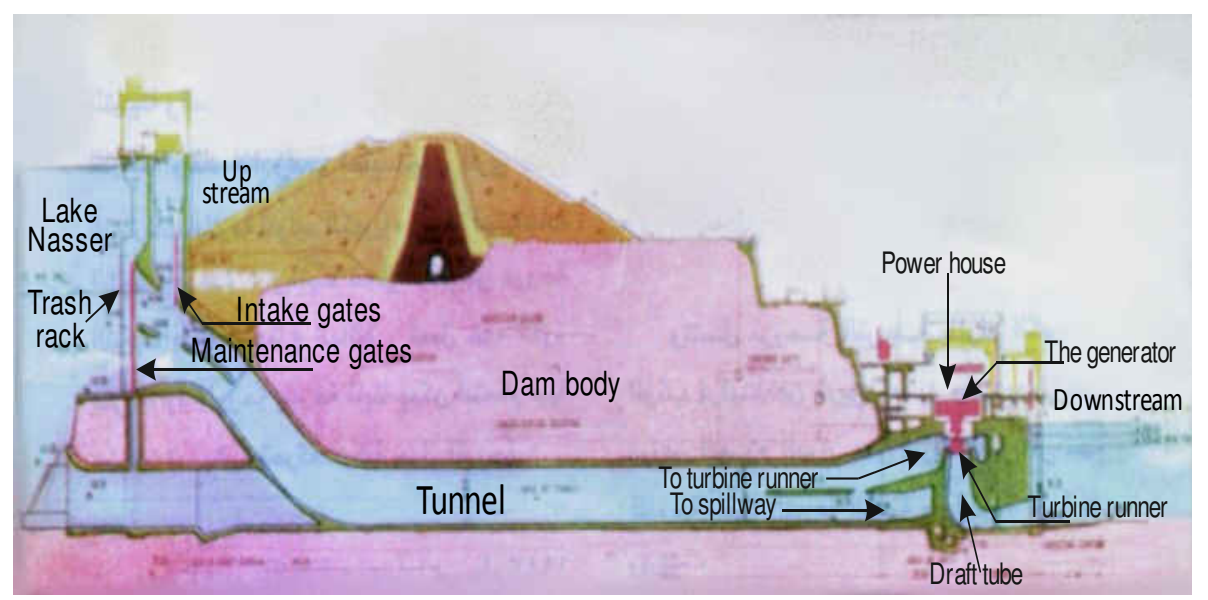

Fig. 1. Sectional view of Aswan High Dam and its hydro-power plant.

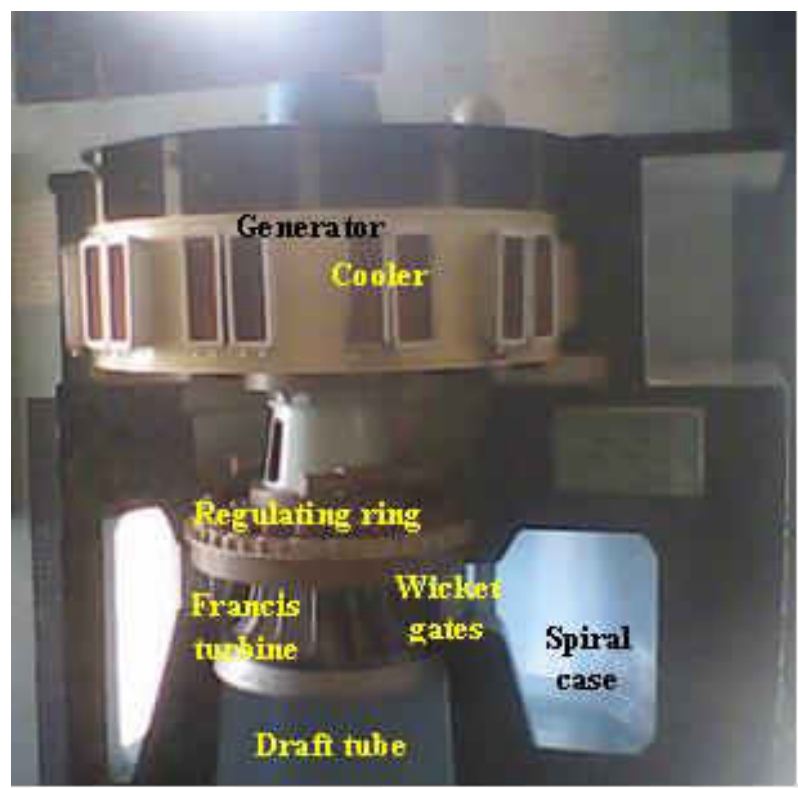

Fig. 2. Sectional model of the hydro-power unit.

Journal of Engineering Sciences, Assiut University, Faculty of Engineering, Vol. 41, No. 3, May, 2013,E-mail address: jes@aun.edu.eg 
A. Kahoul et al., Performance study of generator air coolers for the hydro-power plant at Aswan high dam, pp. 1054 - 1077

Figure 3 shows a detailed sectional view of the generator and associated typical cooling system for enclosed housings. The Performance related components of the typical generator cooling system consists of fan blades mounted on the rotor, cooling water system, and generator air coolers [11]. The figure shows the cooling air circulation path in the generator cooling system. The main parts of the generator are: the rotor carrying the excitation poles, and the stator consisting of frame, core and windings.

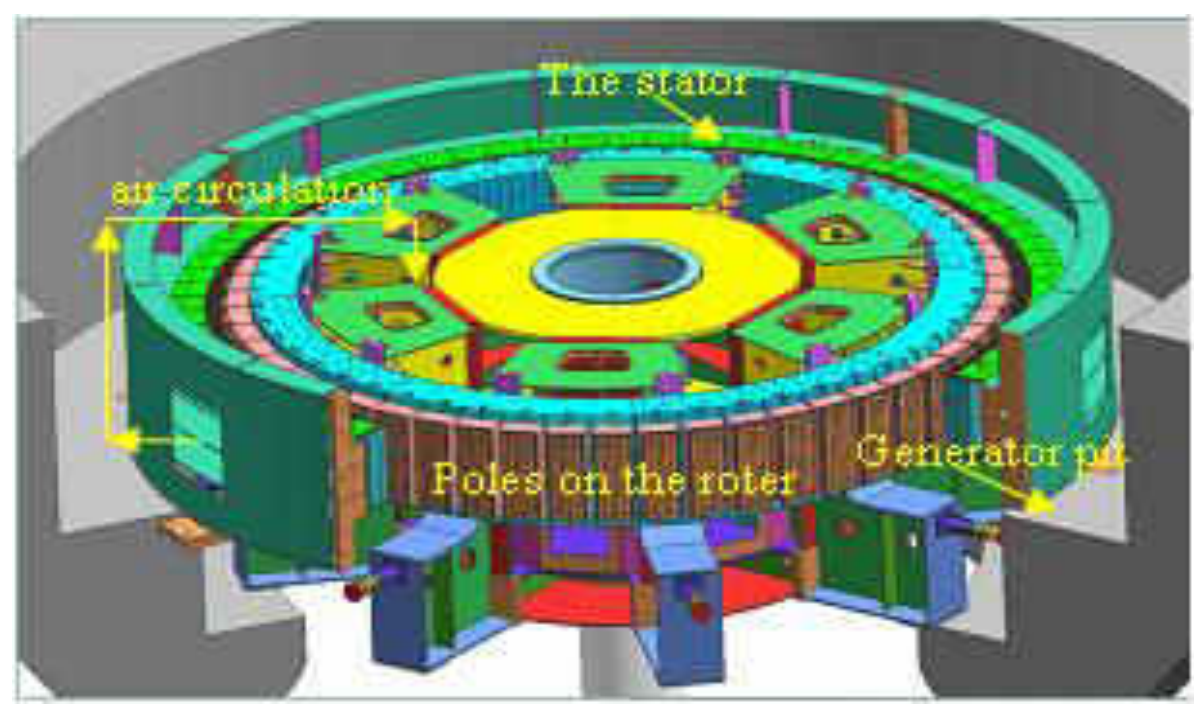

Fig.3. Sectional view of the generator.

Figure 4 shows a plan view for the main site features of the power house in the hydropower plant. The features include the High Dam body located upstream the power house with the forebay to control the water flow from Lake Nasser towards the hydro-power units in the power house. The twelve units are located in such a manner to keep a camp area for maintenance and workshop operations. It is worth noting that the unit U12 is positioned at the extreme west location where the intake water is liable to carry more dirt and silt. Figure 5 shows a photograph for the hydro-power units inside the power house with its mechanical and electrical auxiliaries. The photograph is taken from a place above the unit U12.

\section{Experimental work}

The aim of this section is to present the details of the experimental work including layout of the flow configuration of the air-water coolers together with their main design features and specifications. The section also presents a brief description of the feed and drainage loop for the cooling water with connection to the twelve coolers of a representative hydro-power unit. The measuring procedure for air temperatures and cooling water pressures is presented.

Journal of Engineering Sciences, Assiut University, Faculty of Engineering, Vol. 41, No. 3, May, 2013, E-mail address: jes@aun.edu.eg 
A. Kahoul et al., Performance study of generator air coolers for the hydro-power plant at Aswan high dam, pp. 1054 - 1077

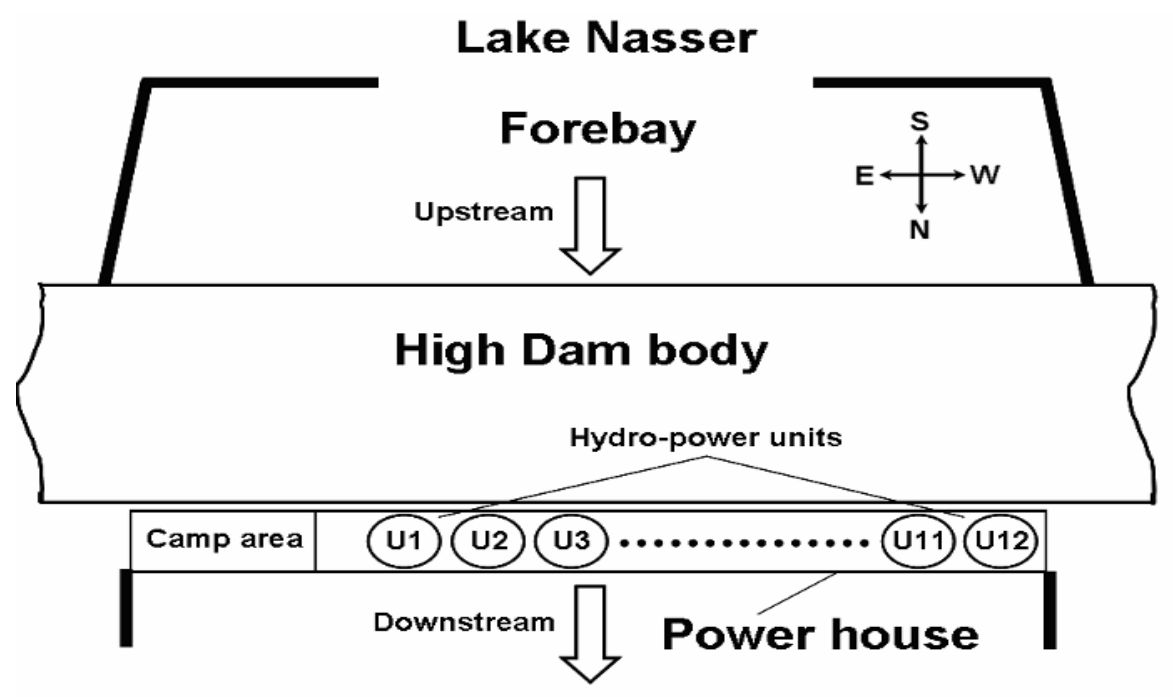

Fig. 4. Site features of the power house in Aswan hydro-power plant.

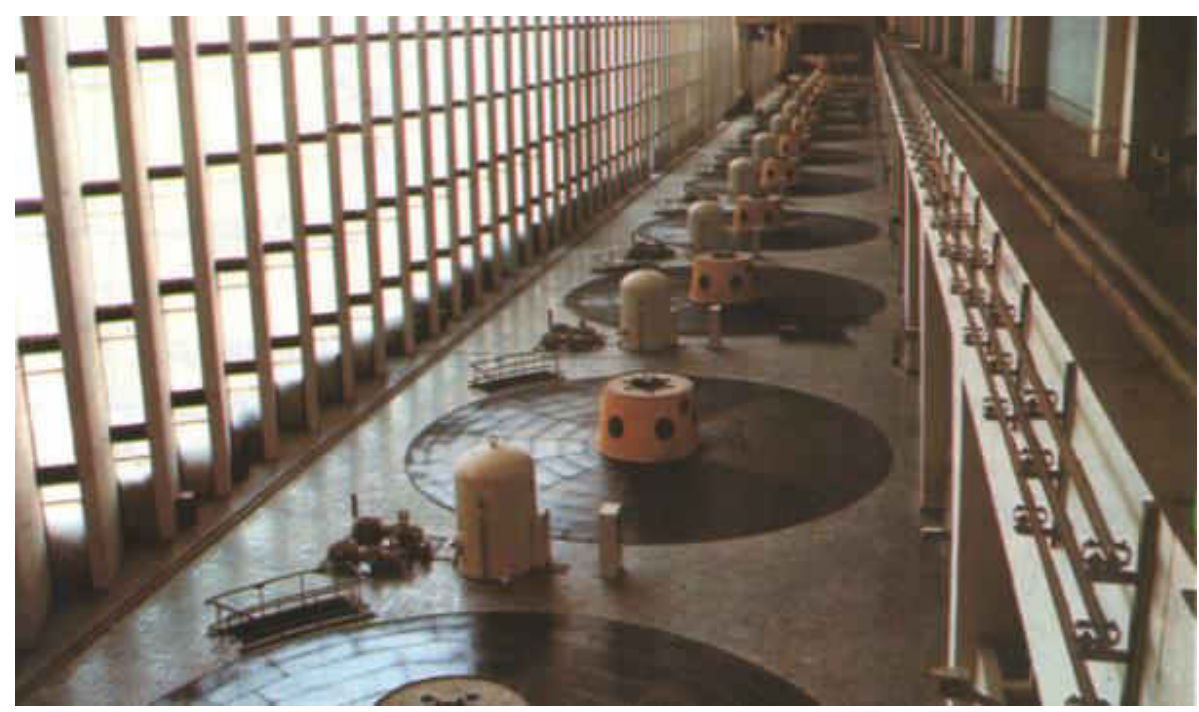

Fig. 5. Photographic view inside the power house.

\subsection{Flow Configuration of the Air-water Coolers}

Figure 6 shows the representative flow configuration in the two tube-bundles of the air-water coolers for both original (Fig. 6-a) and new

(Fig. 6-b) designs. The flow configuration of one cooler is described by the air flow pass in each tube-bundle crossing the water flow pass through the tubes. The flow passes are

Journal of Engineering Sciences, Assiut University, Faculty of Engineering, Vol. 41, No. 3, May, 2013,E-mail address: jes@aun.edu.eg 
A. Kahoul et al., Performance study of generator air coolers for the hydro-power plant at Aswan high dam, pp. 1054 - 1077

characterized by the mass flow rates $n \alpha_{a}$ and $n k_{w}$, inlet temperatures $T_{h}$ and $T_{w, i n}$, and outlet temperatures $\mathrm{T}_{\mathrm{c}}$ and $\mathrm{T}_{\mathrm{w}, \mathrm{out}}$, as well as the inlet and the outlet water pressures $\mathrm{P}_{\text {in }}$ and $\mathrm{P}_{\text {out }}$. The water flow in the original cooler makes two tubepasses for each tube-bundle. On the other hand, the water flow in the new cooler makes one tube-pass for each tube-bundle. The design and operating conditions of the generator keep the air flow rate $n \&$ for both coolers nearly fixed at an average value of $9.3 \mathrm{~kg} / \mathrm{s}$. The design of the water loops and pumping conditions result in water flow rates $n_{w}$ nearly fixed at average value of $18.61 \mathrm{~kg} / \mathrm{s}$ for the original cooler and $8.19 \mathrm{~kg} / \mathrm{s}$ for the new cooler.

\subsection{Design features and specifications of the coolers}

Figure 7 shows the layout and the main design features for one tube-bundle of the tested cross flow air-water coolers. Each tube-bundle of the original cooler (Fig. 7-a) consists of six rows, each row having twenty two identical tubes in staggered arrangement. The tube-bundle of the new cooler (Fig. 7-b) has two rows, each row having thirty identical tubes in staggered arrangement. The tube bundle of each cooler is described by finned tube-bank with design characteristics as given by Shah and Sekulic [12] and dimensions shown in Fig. 7-c. These characteristics and dimensions are necessary for the calculations of the convective heat transfer coefficients at both air and water sides. Table 1 summarizes the main design specifications of the tube-bundles for both coolers.
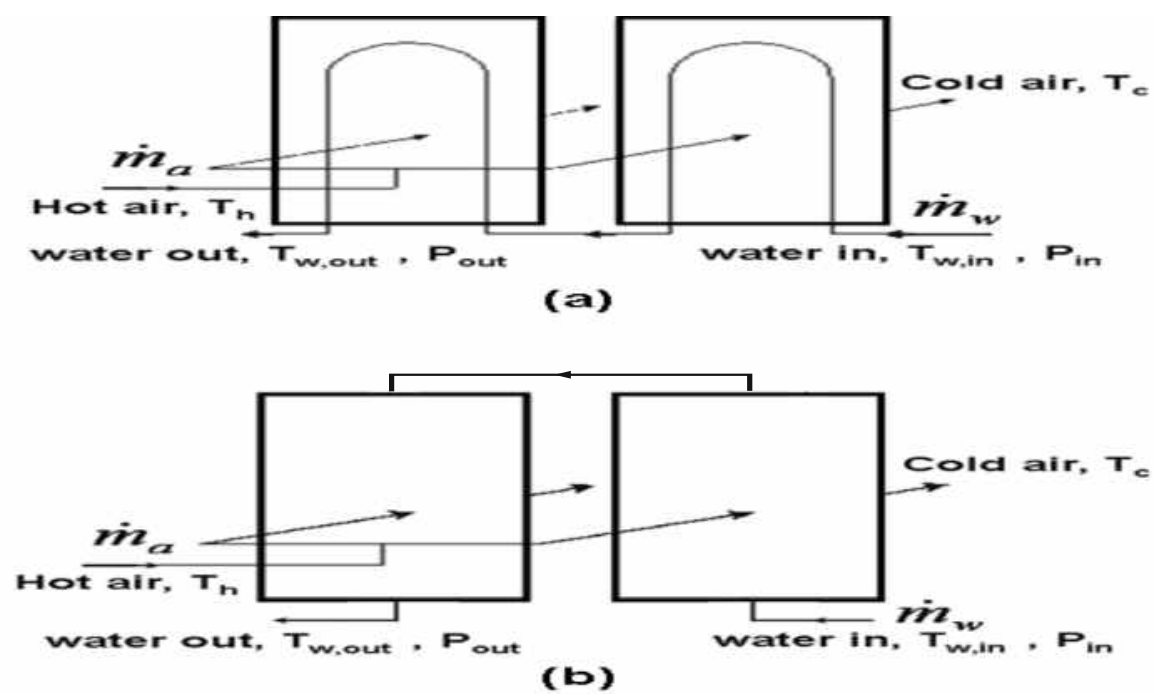

Fig. 6. Air and water flow passes for: (a) Original cooler and (b) New cooler.

Journal of Engineering Sciences, Assiut University, Faculty of Engineering, Vol. 41, No. 3, May, 2013, E-mail address: jes@aun.edu.eg 
A. Kahoul et al., Performance study of generator air coolers for the hydro-power plant at Aswan high dam, pp. 1054 - 1077

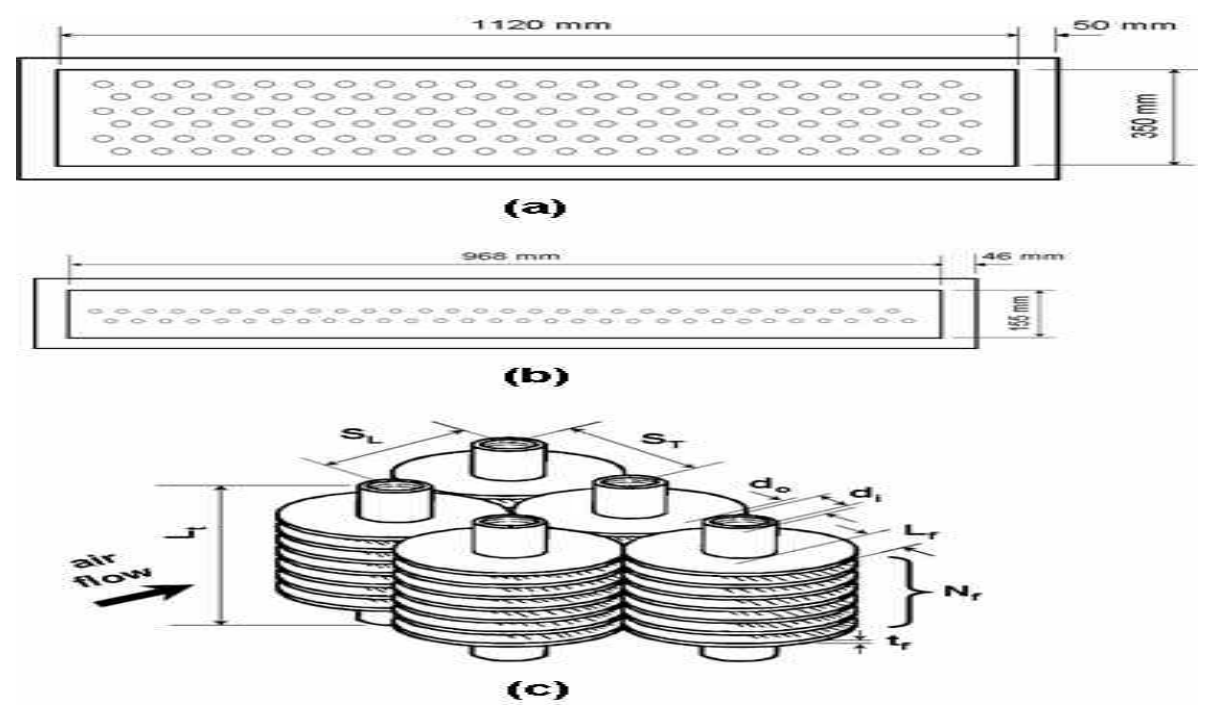

Fig. 7. Layout and design features of the tested cross flow air-water coolers:

(a) tube bundle arrangement of the original cooler,

(b) tube bundle arrangement of the new cooler, and

(c) design characteristics and dimensions of the finned tube-bank.

\section{Table 1.}

Design specifications of the tube-bundle for each cooler.

\begin{tabular}{lcc}
\hline \hline \multicolumn{1}{c}{ Item } & Original cooler & New cooler \\
\hline Tube bundle arrangement & staggered & staggered \\
Tube diameters $\mathrm{d}_{\mathrm{i}} / \mathrm{d}_{\mathrm{o}}, \mathrm{mm}$ & $17 / 19$ & $14 / 16$ \\
Longitudinal pitch of tube bank $\mathrm{S}_{\mathrm{L}}, \mathrm{mm}$ & 43.3 & 43.3 \\
Transverse pitch of tube bank $\mathrm{S}_{\mathrm{T}}, \mathrm{mm}$ & 50 & 50 \\
Number of tube rows & 6 & 2 \\
Number of tubes per row & 22 & 30 \\
Tube bundle length $\mathrm{L}_{\mathrm{t}}, \mathrm{m}$ & 2.6 & 2.48 \\
Fin geometry & annular & annular \\
Fin thickness $\mathrm{t}_{\mathrm{f}}, \mathrm{mm}$ & 0.2 & 0.2 \\
Fin length $\mathrm{L}_{\mathrm{f}}$, mm & 12 & 12 \\
Number of fins per meter of tube length $\mathrm{N}_{\mathrm{f}}, \mathrm{m}^{-1}$ & 394 & 394 \\
Air flow frontal area dimensions, m & $2.6 \times 1.12$ & $2.48 \times 0.83$ \\
Tubes and fins material & copper & copper \\
\hline \hline
\end{tabular}

Journal of Engineering Sciences, Assiut University, Faculty of Engineering, Vol. 41, No. 3, May, 2013,E-mail address: jes@aun.edu.eg 
1061

A. Kahoul et al., Performance study of generator air coolers for the hydro-power plant at Aswan high dam, pp. 1054 - 1077

\subsection{Measuring procedure}

Figure 8 shows the measuring locations and main features of the cooling water loop for feed and drainage of the air-water coolers in one hydro-power unit. The twelve air-water coolers are connected to the inlet and outlet collectors of the cooling water loop through manually controlled valves (Fig. 8-a). The cooling water is supplied to the inlet collector through two main operating filters. The pressures at inlet and outlet of the water loop are measured at two representative locations using digital manometers. The air temperatures are measured using resistive temperature detectors. Figure 8-b shows the measuring locations of hot and cold air temperatures. The temperature of the well-mixed hot air is measured at two representative locations. The temperature is measured for the cold air exiting from each cooler of the twelve coolers in the power unit.

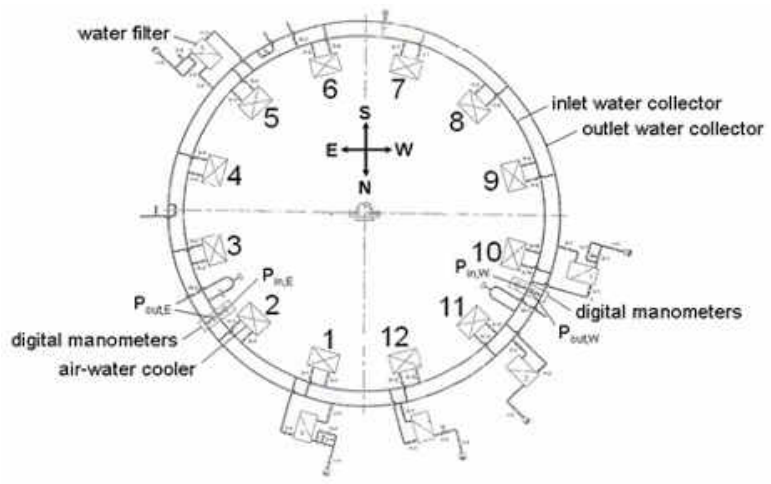

(a)

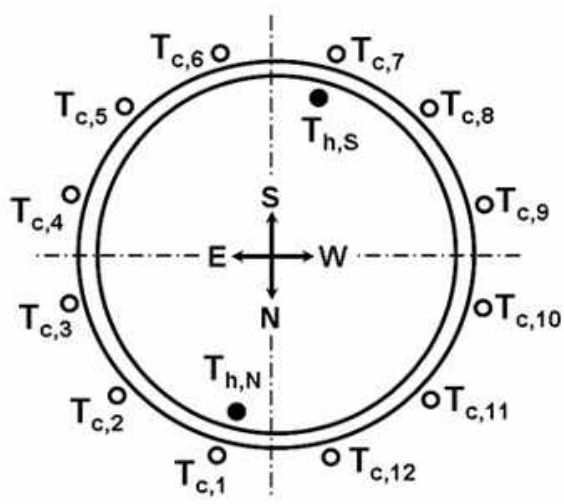

(b)

Fig. 8. Main features of the cooling water loop:

(a) inlet and outlet water collectors with their connections and

(b) measuring locations of air temperatures.

Journal of Engineering Sciences, Assiut University, Faculty of Engineering, Vol. 41, No. 3, May, 2013,E-mail address: jes@aun.edu.eg 
A. Kahoul et al., Performance study of generator air coolers for the hydro-power plant at Aswan high dam, pp. 1054 - 1077

\section{Analysis of the experimental results}

In this section analysis is performed on the hot and cold air temperatures together with the cooling water pressures measured for the twelve coolers of each hydro-power unit (Fig. 8). The measured values are processed to obtain some results that are useful for the discussion in the present study. These results describing the cooler performance are calculated using the following mathematical relations. The cooler is treated as a heat exchanger (Figs. 6 and 7) with cooling water flowing inside finned tubes (unmixed cold fluid) in cross flow of the hot circulating air (unmixed hot fluid).

Referring to Fig. 8, average values of air temperature drop $\left(-\delta \mathrm{T}_{\mathrm{a}}\right)$ and water pressure drop $(-\Delta \mathrm{P})$ for the cooler are calculated by

$$
\left(-\delta T_{a}\right)=T_{h, a v e}-\frac{\sum_{i=1}^{12} T_{c, i}}{12},
$$

Where $T_{h, a v e}$ is average hot air temperature given by

$$
\begin{aligned}
& T_{h, a v e}=\left(T_{h, N}+T_{h, S}\right) / 2, \\
& (-\Delta P)=\frac{P_{i n, W}+P_{i n, E}}{2}-\frac{P_{o u t, W}+P_{o u t, E}}{2} .
\end{aligned}
$$

Consider the cooler $i(i=1,2,3, \ldots, 12)$ operating with the conditions shown in Fig. 6. for a specified unit. The thermal performance of the cooler $i$ is commonly described by the following linked equations of thermal energy balances and heat transfer.

$$
\begin{aligned}
& q=n \&_{w}^{k} c_{p w}\left(T_{w, \text { out }, i}-T_{w, i n}\right), \\
& q=\operatorname{kog}_{a} c_{p a}\left(T_{h, a v e}-T_{c, i}\right), \\
& q=2 U_{D} A_{o} \Delta T_{m},
\end{aligned}
$$

where $U_{D}$ is the overall heat transfer coefficient based on the outer surface area $A_{o}$ of the non-finned tubes in one tube-bundle for actual dirt (fouled) conditions. The mean temperature difference, $\Delta T_{m}$ is given by

$$
\Delta T_{m}=F_{T} \cdot L M T D,
$$

where LMTD is the logarithmic mean of the temperature differences at the terminal of the equivalent counterflow double-pipe heat exchanger. The factor $F_{T}$ is the temperature correction factor for a cross flow with both fluids unmixed.

Journal of Engineering Sciences, Assiut University, Faculty of Engineering, Vol. 41, No. 3, May, 2013,E-mail address: jes@aun.edu.eg 
1063

A. Kahoul et al., Performance study of generator air coolers for the hydro-power plant at Aswan high dam, pp. 1054 - 1077

A fouling factor $R_{f}^{\prime \prime}$ acting in the water side of the tubes in one bundle can be estimated by

$$
\frac{R_{f}^{\prime \prime}}{A_{i}}=\frac{1}{U_{D} A_{o}}-\frac{1}{U_{C, \text { with fins }} A_{o}},
$$

where $A_{i}$ is the inside area of the tubes in one tube-bundle. The clean overall heat transfer coefficient $U_{C \text {, with fins }}$ for finned tubes in cross flow, is given by

$$
\frac{1}{U_{C, \text { with fins }} A_{o}}=\frac{1}{h_{i} A_{i}}+R_{\text {cond }}+\frac{1}{\eta_{o} h_{t} A_{t}}
$$

where $R_{\text {cond }}$ is the total tube wall conduction resistance. The inner convective heat transfer coefficient $h_{i}$ is calculated for water flow inside the tubes using the heat transfer equation for internal flow [13]. The average value of the outer convective heat transfer coefficient $h_{t}$ for air cross flow over the finned tubes, is calculated using the heat transfer empirical correlations for cross flow over a bank of finned tubes with annular fins [14]. The finned tube geometric characteristics $\eta_{o}$ and $A_{t}$ are the overall surface efficiency and the total surface area of the tube-bundle, respectively.

The effectiveness, $\varepsilon$ of the cooler $i$ is calculated by

$$
\varepsilon=\frac{\left(T_{h, \text { ave }}-T_{c, i}\right)}{\left(T_{h, \text { ave }}-T_{w, \text { in }}\right)}
$$

The corresponding number of transfer units $(N T U), N$ of the cooler $i$ is calculated by

$$
N=\frac{U_{D} A_{o}}{C_{\min }},
$$

where $C_{\text {min }}={ }_{k} k_{a} c_{p a}$ is the minimum heat capacity rate of the cooler.

For comparison, the following empirical relation for cross flow heat exchangers with both fluids unmixed [15] is used to express the effectiveness $\varepsilon$ as a function of the number of transfer units $N$.

$$
\varepsilon=1-\exp \left[\frac{\exp (-N C n)-1}{C n}\right]
$$

where the index $n$ is given in terms of the number $N$, by

$$
n=N^{-0.22}
$$

Journal of Engineering Sciences, Assiut University, Faculty of Engineering, Vol. 41, No. 3, May, 2013,E-mail address: jes@aun.edu.eg 
A. Kahoul et al., Performance study of generator air coolers for the hydro-power plant at Aswan high dam, pp. 1054 - 1077

The parameter $C$ is the ratio of the minimum heat capacity rate $C_{\min }$ to the maximum heat capacity rate $C_{\max }=n_{w}^{k} c_{p w}$.

\section{Results and discussion}

Measurements of the circulating hot and cold air temperatures have been monitored together with the records of the generated electric power under varying operating conditions. The variation in the operating conditions occurs with time variation of the generated power and with the locations of the air-water coolers and power units. Measurements over total time duration of 1008 operating hours have been collected. The measurements also included the inlet and exit cooling water pressures of the air-water coolers, at specified conditions. The total operating hours covered 42 different days in the summer season. The directly measured temperatures were analyzed to obtain the other results describing the performance of the air-water coolers under different operating conditions. The discussion is carried out on both results classified into the following five groups:

1. Diurnal variations of the air temperatures and generated electric power.

2. Diurnal variations of the average air temperature drop and average water pressure drop.

3. Daily variation of the accumulated fouling in the air-water coolers.

4. Effectiveness-NTU performance behaviour of the air-water coolers.

5. Thermal performance characteristics of the cooler.

\subsection{Diurnal variations of the air temperatures and generated electric power}

Figures 9-11 show the effects of the operating conditions and the cooler designs on air cooling characteristics. These characteristics are described by the diurnal variations of the measured hot and cold air temperatures. The variation in the hot air temperatures follows mostly the variation in the generated electric power either over the daily hours or due to the change from unit to another. This is obvious due to mainly the strong relation of the heat dissipated from the generator with the generated electric power. The results show that the generated electric power is rated at $175 \mathrm{MW}$. Also, the variations in the hot air temperatures and the cold air temperatures are mutually affected by each other. The figures clearly show that the values of the measured hot air temperatures $\left(T_{h, N}\right.$ and $\left.T_{h, S}\right)$ are about to coincide overall operating conditions. This implies the good uniformity of the hot air temperature around the generator, indicating good flow behaviour of the circulating air. On the other hand, noticeable differences exist between the measured temperatures of the cold air exiting from the twelve air coolers located around the generator of each unit. This is true for both cooler designs. The differences in cold air temperature can be explained based on the following interrelated factors. As shown in Fig. 8, the twelve coolers are positioned at different locations with respect to both inlet and outlet water collectors. Moreover, the coolers are connected to both collectors through manually controlled valves. Also, the cooling water is supplied to the inlet collector through Journal of Engineering Sciences, Assiut University, Faculty of Engineering, Vol. 41, No. 3, May, 2013,E-mail address: jes@aun.edu.eg 

high dam, pp. 1054 - 1077

two main operating filters. The other three shown filters are used each as a reserve for the operating filters when they are under maintenance. These factors probably produce the mentioned temperature differences of the cold air exiting from the twelve coolers depending on their locations, adjustment of inlet and exit valves openings, and the condition of the water supply filter.

Figures 9 and 10 show mainly the effects of the operating conditions on the performance of the original air-water coolers as characterized by the diurnal variation of the cold air temperatures. Figure 9 shows the effect of the power unit location illustrated by the results on day 23/8/2006 for separate units; U1, U5, U8, and U12 at different locations within the power house (Fig. 4). Figure 10 shows the effect of generated power variation illustrated by the results of unit U6 for separate operating days. The variation in the generated electric power usually occurs with variation in power load or irrigation demands, as well as with time for maintenance. Figure 9-A, B, and $\mathrm{C}$ shows that the temperatures of the cold air exiting from the original coolers lie between $30^{\circ} \mathrm{C}$ and $40^{\circ} \mathrm{C}$ with a range of $10 \mathrm{C}$ for the units U1, U5, and U8. On the other hand, Fig. 9-D shows higher cold air temperatures $\left(38^{\circ} \mathrm{C}-48^{\circ} \mathrm{C}\right)$, with the same range of $10 \mathrm{C}$ for unit $\mathrm{U} 12$. This is due to the accumulation of much fouling associated with the extreme location of this unit. The intake of the cooling water at such location is exposed to much dirt and silt, compared with the locations of the other units, due to the slow flow of the water stream. The mentioned ranges of the cold air temperatures suggest that the cooler performance results in a mean cold air temperature with a maximum deviation of about $\pm 5 \mathrm{C}$ under different operating conditions. Figure 9-D shows that within the stoppage period (no power generation) the cold air temperatures approach each other at higher values near to the values of the hot air temperatures. This is due to the stoppage of the forced air circulation produced by the rotor motion. The same behavior can be found for the unit U6 in Fig. 10-A and $\mathrm{C}$. The diurnal variation in the generated power shown in Fig. 10 produces similar variations in both hot and cold air temperatures. This is clear for instants of generated power drop in Fig. 10-A and E. The values of the hot air temperatures, with the original coolers under different operating conditions, lie sufficiently below the normal design temperature range $\left(60^{\circ} \mathrm{C}-80^{\circ} \mathrm{C}\right)$ for the generator core and coils. This situation enables the continuity of effective heat transfer between the generator components and the circulating cooling air.

Figure 11 shows the results for the new coolers working with the new generator of unit U9 on different summer days. The cold air temperatures for the twelve coolers of the unit U9 exhibit higher values with narrow range of temperature differences compared with those for the original coolers (Figs. 9 and 10). These combined characteristics of the new coolers indicate the short operating period from the beginning at year 2005, together with insufficient geometrical design characteristics (Fig. 7-b and Table 1). The corresponding hot air temperatures in Fig. 11-C and $\mathrm{E}$ approach the minimum value of the normal design temperature range for the generator components, resulting in bad cooling of the generator.

Journal of Engineering Sciences, Assiut University, Faculty of Engineering, Vol. 41, No. 3, May, 2013,E-mail address: jes@aun.edu.eg 
A. Kahoul et al., Performance study of generator air coolers for the hydro-power plant at Aswan high dam, pp. 1054 - 1077

Such situation clearly shows the incorrect decision of selecting incompatible new coolers to operate with the new generators.
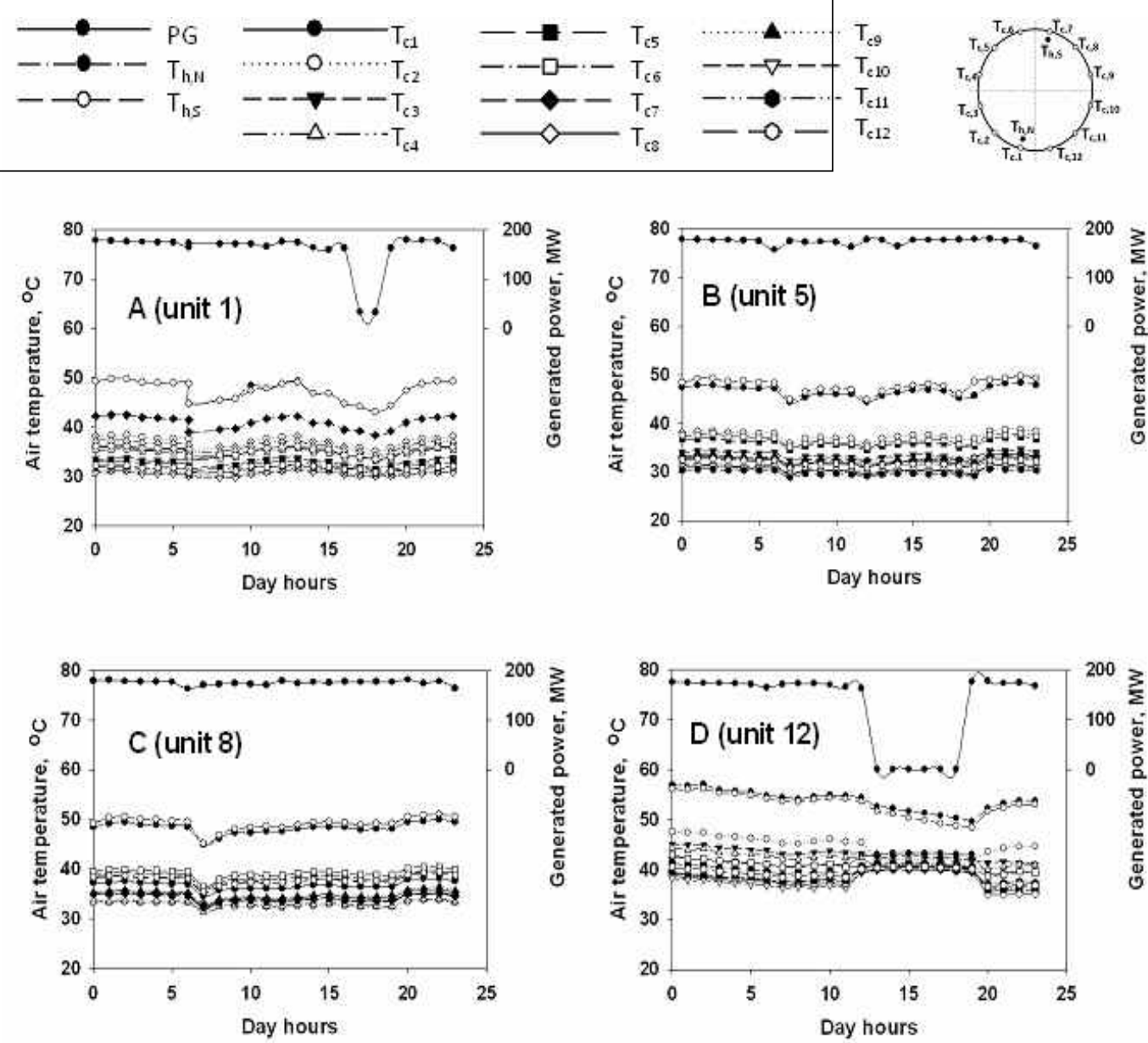

Fig. 9. Effect of power unit location on the performance of the original air-water coolers.

Journal of Engineering Sciences, Assiut University, Faculty of Engineering, Vol. 41, No. 3, May, 2013,E-mail address: jes@aun.edu.eg 
A. Kahoul et al., Performance study of generator air coolers for the hydro-power plant at Aswan high dam, pp. 1054 - 1077
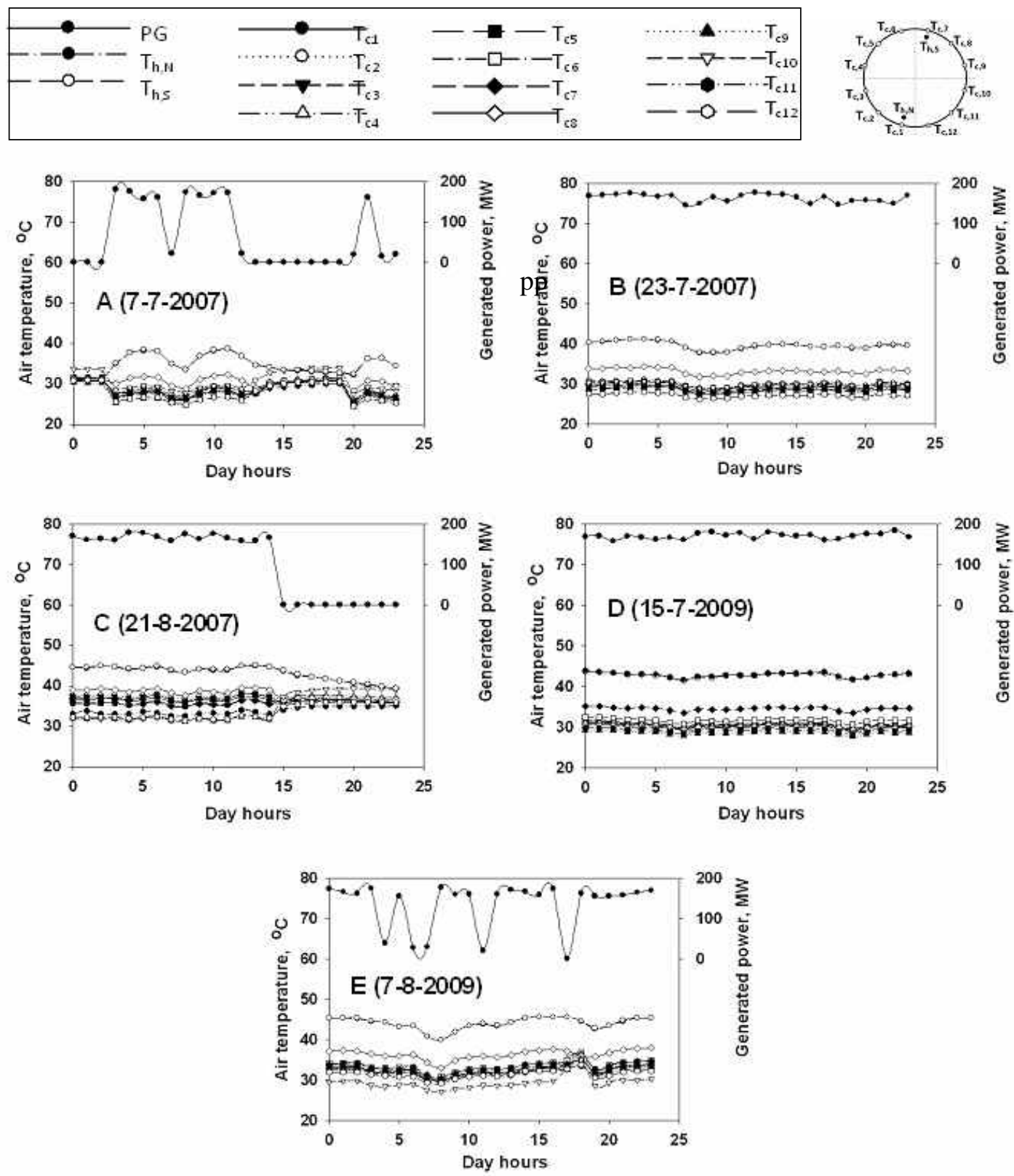

Fig. 10. Effect of generated power variation on the perfoermance of the original air-water coolers in unit U6.

Journal of Engineering Sciences, Assiut University, Faculty of Engineering, Vol. 41, No. 3, May, 2013,E-mail address: jes@aun.edu.eg 
A. Kahoul et al., Performance study of generator air coolers for the hydro-power plant at Aswan high dam, pp. 1054 - 1077
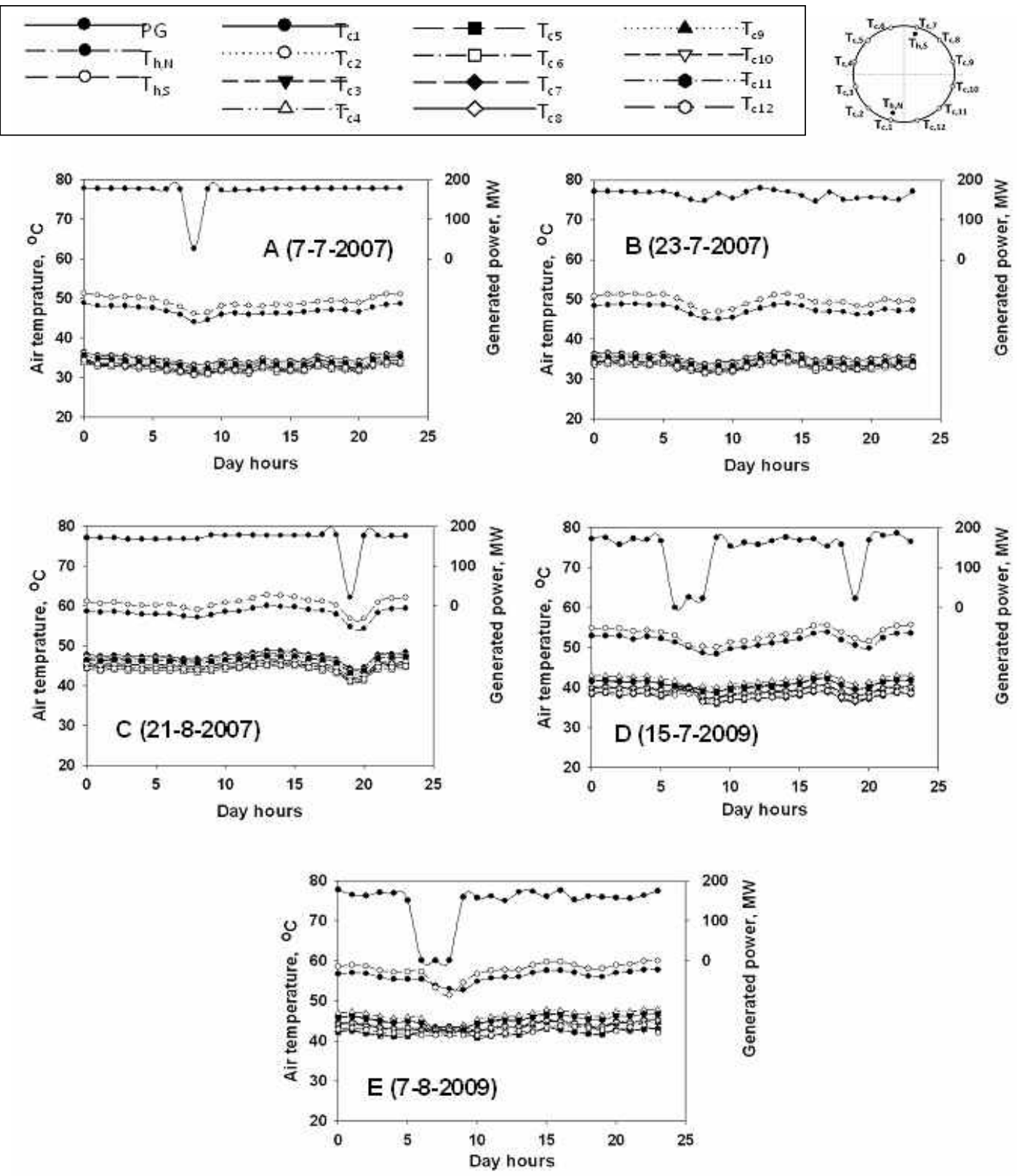

Fig. 11. Effect of generated power variation on the performance of the new airwater coolers in unit U9.

Journal of Engineering Sciences, Assiut University, Faculty of Engineering, Vol. 41, No. 3, May, 2013,E-mail address: jes@aun.edu.eg 
A. Kahoul et al., Performance study of generator air coolers for the hydro-power plant at Aswan high dam, pp. 1054 - 1077

\subsection{Diurnal variations of the average air temperature drop and average water pressure drop}

Figure 12 shows the effect of the power unit location on the performance of the original air-water coolers described by the diurnal variations of the average air temperature drop $\left(-\delta T_{a}\right)$ and average water pressure drop $(-\Delta P)$. The results of Fig. 12 are associated with the results for the air cooling characteristics in Fig. 9, and add more information about the air-water heat exchange in the coolers. The average water pressure drop is directly related to the mass rate of the cooling water flowing inside the coolers tubes. Figure 12-A, B, and $\mathrm{C}$ show that the average water pressure drop for the units U1, U5, and U8 is nearly constant with time at a value of $100 \mathrm{kPa}$. The corresponding results in Fig. 12-D for unit U12 show different behavior. The average water pressure drop is kept nearly constant at a higher value of $120 \mathrm{kPa}$ up to an instant at which the water flow is stopped. The stoppage of water flow with no power generation (Fig. 9-D) was mainly done as there is no need for cooling water. Also, the stoppage of the water flow may be done for maintenance reasons. The effective cooler performance requires constant mass flow rate for the cooling water of all original coolers in all units. Consequently, the resulting average pressure drop is expected to be constant (Fig. 12-A, B, and C). The higher constant value of the water pressure drop in Fig. 12$\mathrm{D}$ can be clearly explained by the accumulation of much fouling as discussed in the previous section.

The average air temperature drop has a value about $15^{\circ} \mathrm{C}$ for the operating condition with the power generation at the rated value of 175 MW. The air temperature drop and by turn the cooling effect decrease with the decrease in power generation. This situation does not imply weak performance of the coolers because the cooling effect produces hot air temperatures at power generation less than the rated value. The results in Fig. 12-D indicate the occurrence of cooling effect of the coolers with decreasing rates, in spite of the stoppage of both the cooling water flow and the forced air circulation. This situation can be explained as the heat transfer between the air and the cooling water still exists with free convection at both air and water sides.

Journal of Engineering Sciences, Assiut University, Faculty of Engineering, Vol. 41, No. 3, May, 2013, E-mail address: jes@aun.edu.eg 
A. Kahoul et al., Performance study of generator air coolers for the hydro-power plant at Aswan high dam, pp. 1054 - 1077
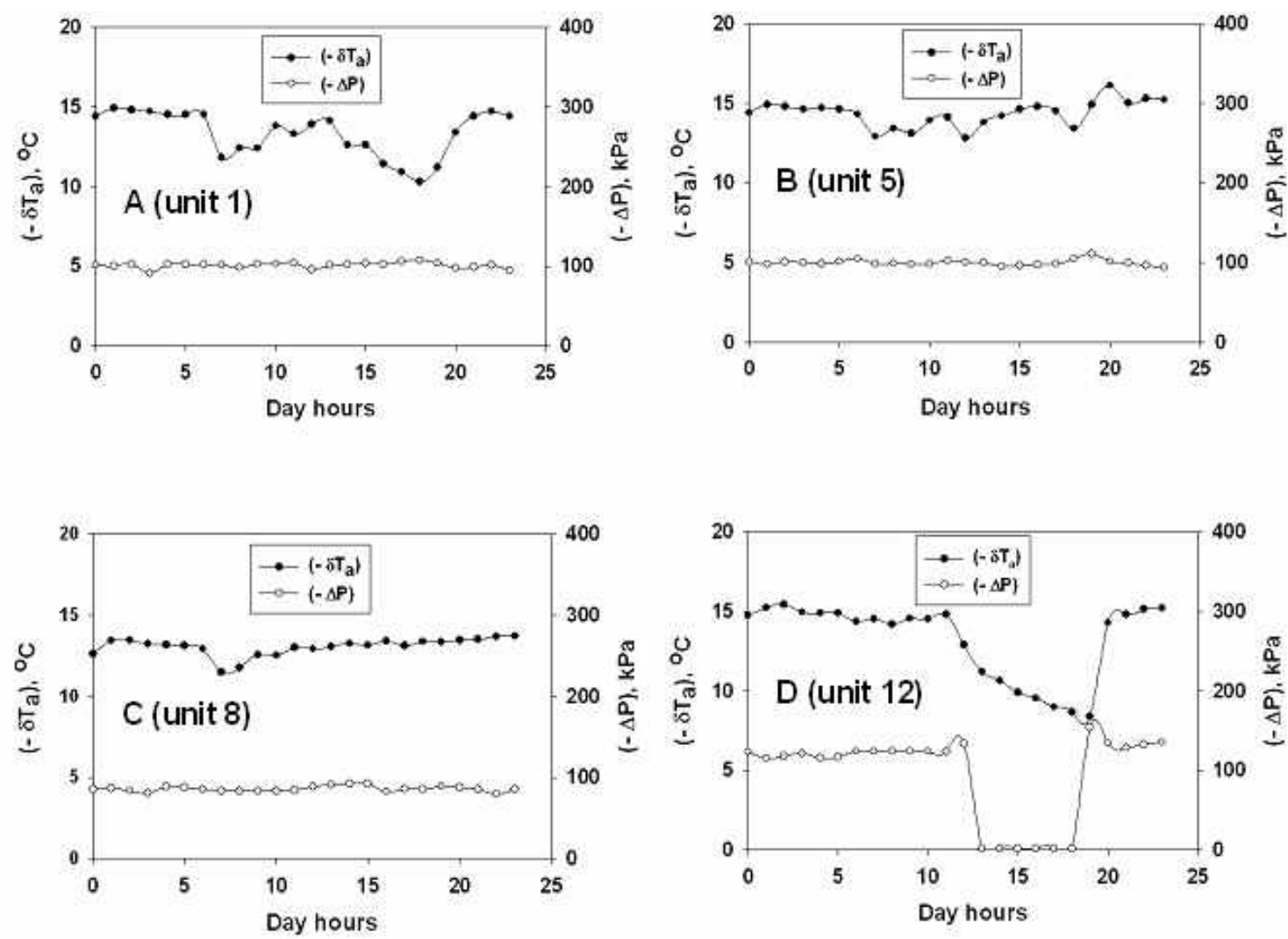

Fig. 12. Effect of power unit location on average air temperature drop and average water pressure drop for the original air-water coolers.

\subsection{Daily variation of the accumulated fouling in the air-water coolers}

Figure 13 shows the experimental results of the accumulated fouling in the original coolers of unit U6 (Fig. 13-A) and the new coolers of unit U9 (Fig. 13B). These results are based on measurements for twelve days distributed over July and August summer months for years 2007 and 2009. The accumulated fouling mostly occurs inside the water copper tubes of the coolers due to two mechanisms. The main mechanism is due to the deposition of dirt and silt. The other mechanism is due to the corrosion and erosion of the copper material of the water tubes. The plots in Fig. 13 represent the daily values of the fouling factor $R_{f}^{\prime \prime}\left(\mathrm{m}^{2} . \mathrm{K} / \mathrm{W}\right)$ for the twelve coolers of each unit. Figure 13 shows vertical strings of points representing the results for most (original) or all (new) of the twelve coolers. These strings indicate that all tubes of the coolers are non-defected and operating well. This situation is clearly shown for all the twelve new coolers (Fig. 13-B). On the other hand, the points representing the results for some original

Journal of Engineering Sciences, Assiut University, Faculty of Engineering, Vol. 41, No. 3, May,

2013,E-mail address: jes@aun.edu.eg 
1071

A. Kahoul et al., Performance study of generator air coolers for the hydro-power plant at Aswan high dam, pp. 1054 - 1077

coolers are scattered with large $R_{f}^{\prime \prime}$ far from the corresponding strings representing the remainder coolers (Fig. 13-A). The scattered points show the malfunction of the corresponding coolers. This indicates that some $(10 \%-15 \%)$ of the tubes of these coolers are defected. They are mostly damaged and blocked. The large values of $R_{f}^{\prime \prime}$ expressing the malfunction of the coolers with blocked tubes, can be understood as the sum of the actual fouling factor and an equivalent one due to the reduction in the heat transfer area. The values of the fouling factor for the original coolers are generally greater than those for the new coolers. This is due to the permanent accumulated corrosion and erosion of the copper tubes of the original coolers working for long period (from 1967 to 2009). On the other hand, the new coolers working for short period (from 2005 to 2009), were not exposed to such corrosion and erosion. The fluctuations in the results are probably due to the non-periodic maintenance. The results show a maximum value of about $60 \times 10^{-4} \mathrm{~m}^{2} . \mathrm{K} / \mathrm{W}$ for the actual fouling factor $R_{f}^{\prime \prime}$ with original coolers having non-defected tubes. The new coolers show a maximum value of $32.4 \times 10^{-4} \mathrm{~m}^{2} . \mathrm{K} / \mathrm{W}$ for the actual fouling factor.

\subsection{Effectiveness-NTU performance behaviour of the air-water coolers}

Figure 14 shows the experimental results of the cooler effectiveness, $\varepsilon$ as varied with the number of transfer units, $N$. These results are based on the measurements used for the results of $R_{f}^{\prime \prime}$ shown in Fig. 13, with the same operating conditions. The figure shows the plots of the experimental results together with the continuous curves representing the published empirical $\varepsilon-N$ relation [14] given by Eq. (12) for both coolers. The experimental results mostly coincide with the curves of the empirical relation, indicating the proper performance of the working coolers as well as the reliability of the considered empirical relation. The distribution of the experimental $N$ values between a minimum of 0.3 to a maximum of 2.01, is mainly due to the variation of the fouling factor $R_{f}^{\prime \prime}$ with the operating conditions. The values of $N$ in Fig. 14-A for the original cooler include larger values up to 2.01, compared with those in Fig. 14-B for the new cooler. These larger values of $N$ correspond to better performance of the original cooler with $\varepsilon$ values up to 0.86 . This good performance of the original cooler seems to be contradicting with the relatively large fouling factors as depicted in Fig. 13-A. The improved performance of the original cooler is reached through the compensation of the smaller values of $U_{D}$ with its larger heat transfer surface area compared with the new cooler.

Journal of Engineering Sciences, Assiut University, Faculty of Engineering, Vol. 41, No. 3, May, 2013, E-mail address: jes@aun.edu.eg 
A. Kahoul et al., Performance study of generator air coolers for the hydro-power plant at Aswan high dam, pp. 1054 - 1077
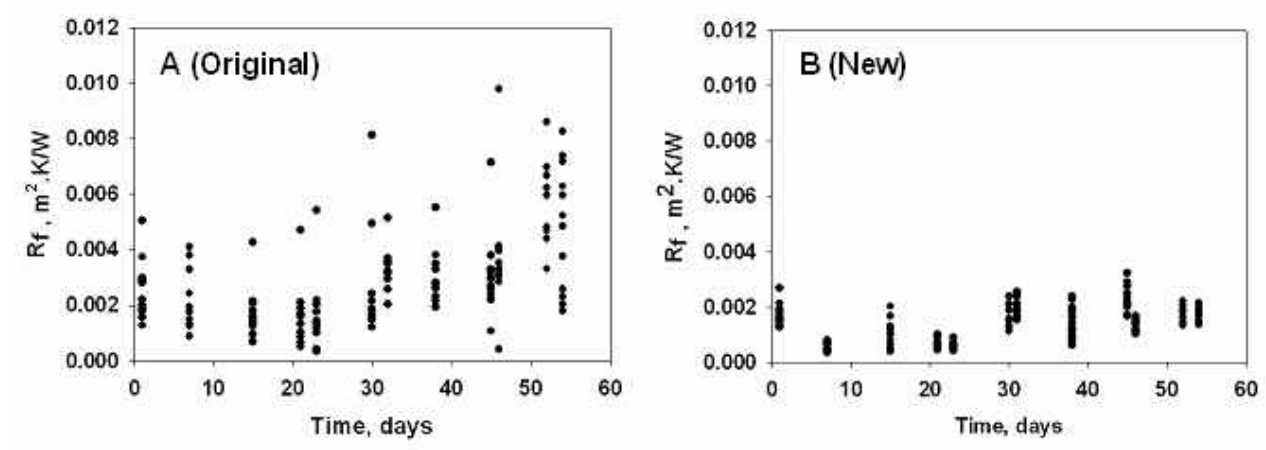

Fig. 13. Daily variation of the fouling factor for the air-water coolers
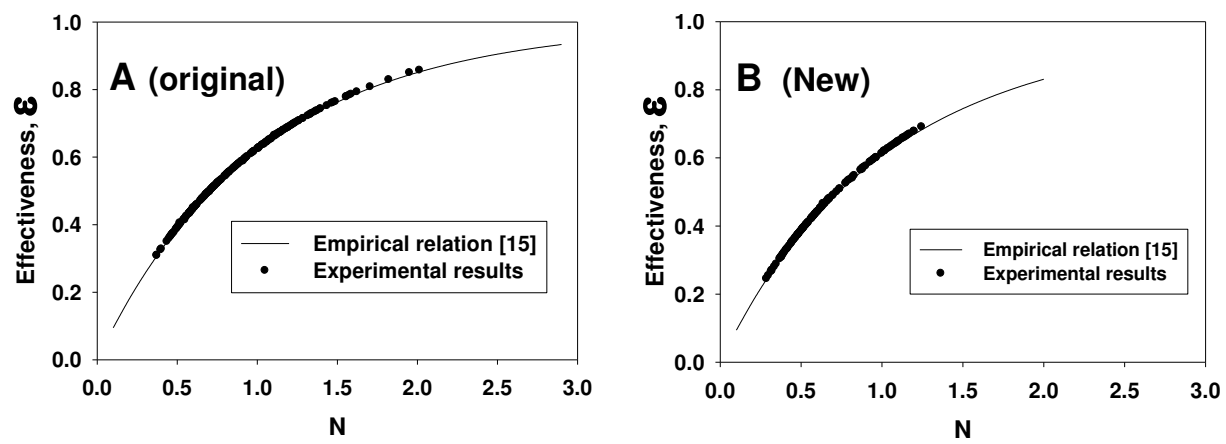

Fig. 14. Effectiveness-NTU performance behaviour of the air-water coolers.

\subsection{Performance characteristics of the air-water coolers}

Table 2 summarizes the main items describing the thermal performance characteristics of the air-water coolers. These items were calculated using the geometrical design characteristics of one tube-bundle representing each cooler together with the measured temperatures. The tube-bundle representing the original cooler possesses inside $\left(\mathrm{A}_{\mathrm{i}}\right)$ and outside $\left(\mathrm{A}_{\mathrm{o}}\right)$ heat transfer surface areas about three times larger than those for the tube-bundle of the new cooler. The small value of $\mathrm{C}_{\max }$ for the new cooler compared with that for the original one is due to the associated small mass flow rate of the cooling water. The corresponding values of the water flow area, $\mathrm{a}_{\mathrm{w}}$ with this situation indicate that the cooling water velocities for both coolers are nearly equal. This is normally expected in view of the fixed water pumping potential energy up to $75 \mathrm{~m}$ head.

Journal of Engineering Sciences, Assiut University, Faculty of Engineering, Vol. 41, No. 3, May,

2013,E-mail address: jes@aun.edu.eg 
1073

A. Kahoul et al., Performance study of generator air coolers for the hydro-power plant at Aswan high dam, pp. 1054 - 1077

The values of $\mathrm{C}_{\min }$ are equal for both coolers, although the new generator differs from the original one. This can be understood with the fixed design and operating conditions associated with the air circulation for both generators. The values of the inside heat transfer coefficient, $h_{i}$ (water side) are much larger $(180-300$ times) compared with those for the outside coefficient, $h_{o}$ (air side). This indicates that the outside coefficient, $h_{o}$ is the dominant one controlling the convective heat transfer. This is clearly shown from the values of the overall coefficient $U_{C}$, without fins. The maximum and minimum values of the actual fouling factor for both coolers give representative average values of $32 \times 10^{-4} \mathrm{~m}^{2} . \mathrm{K} / \mathrm{W}$ for original cooler and $18 \times 10^{-4} \mathrm{~m}^{2} . \mathrm{K} / \mathrm{W}$ for new cooler. These representative values of the actual fouling factor are larger by nearly one order than corresponding recommended TEMA range $(3.5-5.3) \times 10^{-4} \mathrm{~m}^{2} . \mathrm{K} / \mathrm{W}$ for water river [12]. This implies that both coolers were designed with excess heat transfer surface area, to work well for long periods under the normal operating conditions of the present hydropower plant.

\section{Table 2.}

Main thermal performance characteristics of the air-water coolers.

\begin{tabular}{lcc}
\hline \hline \multicolumn{1}{c}{ Item } & $\begin{array}{c}\text { Original } \\
\text { Cooler }\end{array}$ & $\begin{array}{c}\text { New } \\
\text { Cooler }\end{array}$ \\
\hline Total water flow area $\mathrm{a}_{\mathrm{w}}, \mathrm{m}^{2}$ & 0.015 & 0.009 \\
Total air flow frontal area $\mathrm{a}_{\mathrm{a}}, \mathrm{m}^{2}$ & 2.912 & 2.058 \\
Inner surface area of the tubes $\mathrm{A}_{\mathrm{i}}, \mathrm{m}^{2}$ & 18.33 & 6.54 \\
Outer surface area of non-finned tubes $\mathrm{A}_{\mathrm{o}}, \mathrm{m}^{2}$ & 20.48 & 7.48 \\
Total surface area of finned tubes $\mathrm{A}_{\mathrm{t}}, \mathrm{m}^{2}$ & 339.7 & 235 \\
Maximum heat capacity rate $\mathrm{C}_{\max }, \mathrm{W} / \mathrm{K}$ & 77790 & 34230 \\
Minimum heat capacity rate $\mathrm{C}_{\min }, \mathrm{W} / \mathrm{K}$ & 4687 & 4687 \\
Inner heat transfer coefficient $\mathrm{h}_{\mathrm{i}}$ at $\mathrm{A}_{\mathrm{i}}, \mathrm{W} / \mathrm{m}^{2} . \mathrm{K}$ & 5347 & 5531 \\
Outer heat transfer coefficient $\mathrm{h}_{\mathrm{o}}$ at $\mathrm{A}_{\mathrm{o}}, \mathrm{W} / \mathrm{m}^{2} . \mathrm{K}$ & 17.54 & 31.11 \\
Clean coefficient without fins $\mathrm{U}_{\mathrm{C}, \text { without fins }}, \mathrm{W} / \mathrm{m}^{2} . \mathrm{K}$ & 17.43 & 29.36 \\
Clean finned tubes coefficient $\mathrm{U}_{\mathrm{C}, \text { with fins }}, \mathrm{W} / \mathrm{m}^{2} . \mathrm{K}$ & 582 & 1216 \\
Fins enhancement ratio, $\mathrm{U}_{\mathrm{C}, \text { with fins }} / \mathrm{U}_{\mathrm{C}, \text { without fins }}$ & 41.75 & 51.767 \\
Maximum dirt coefficient $\mathrm{U}_{\mathrm{D}, \max }, \mathrm{W} / \mathrm{m}^{2} . \mathrm{K}$ & 479 & 846 \\
Minimum dirt coefficient $\mathrm{U}_{\mathrm{D}, \min }, \mathrm{W} / \mathrm{m}^{2} . \mathrm{K}$ & 81.88 & 235.8 \\
Maximum actual fouling factor $R_{f, \max }^{\prime \prime}, \mathrm{m}^{2} . \mathrm{K} / \mathrm{W}$ & $60 \times 10^{-4}$ & $32.4 \times 10^{-4}$ \\
Minimum actual fouling factor $R_{f, \min }^{\prime \prime}, \mathrm{m}^{2} . \mathrm{K} / \mathrm{W}$ & $3.44 \times 10^{-4}$ & $3.4 \times 10^{-4}$ \\
\hline \hline
\end{tabular}

\section{Conclusions}

The present comparative experimental study was carried out on the performance of generator air coolers for the hydro-power plant of Aswan High Dam. The study investigated the effects of cooler design, time variation of the generated power, and

Journal of Engineering Sciences, Assiut University, Faculty of Engineering, Vol. 41, No. 3, May, 2013,E-mail address: jes@aun.edu.eg 
A. Kahoul et al., Performance study of generator air coolers for the hydro-power plant at Aswan high dam, pp. 1054 - 1077

locations of coolers and power units. The investigation has led to the following main conclusions.

(1) The measured hot air temperatures lie sufficiently below the normal design temperature range $\left(60^{\circ} \mathrm{C}-80^{\circ} \mathrm{C}\right)$ for the generators of most power units. Also, the hot air temperatures show good uniformity indicating good flow behaviour of the circulating air.

(2) The location of the air cooler, adjustment of the inlet and outlet valves for cooling water, and the condition of the water supply filter, are main factors that affect the cooler performance resulting in a mean cold air temperature with a maximum deviation of about $\pm 5 \mathrm{C}$.

(3) The coolers of power units extremely located near to the forebay boundary are exposed to much fouling affecting their performance.

(4) The malfunction of some original coolers expressed by relatively large fouling factors, is equivalent to the reduction in the heat transfer area associated with the blockage of some damaged tubes.

(5) The original coolers suffer from permanent fouling due to accumulated corrosion and erosion of cooler copper tubes.

(6) The effectiveness values for both cooler designs are in good agreement with those obtained by the commonly used empirical $\varepsilon-N$ relation at the same flow condition.

(7) The coolers were designed with excess surface area enabling the coolers to work well for long periods under dirt conditions.

\section{Acknowledgements}

The authors acknowledge the technical support for this study from the authority of the hydro-power plant at Aswan High Dam; especiall thanks are due to Eng. Atef Sadek and Eng. Alaa Farid for help in measurements of the study. Thanks are extended to Dr. Eng. Emad H. El-Zohri, Assistant Professor at Sohag University and Eng. Walid Al-Nahary, Ph D student at Assiut University, for their useful discussions and assistance in preparing and editing the present paper.

\section{Nomenclature}

$\begin{array}{llll}A_{i} & \begin{array}{l}\text { Inner surface area of the tubes, } \\ \mathrm{m}^{2}\end{array} & q & \text { Heat transfer rate, } \mathrm{W} \\ A_{o} & \begin{array}{l}\text { Outer surface area of non- } \\ \text { finned tubes, } \mathrm{m}^{2}\end{array} & P_{\text {in }} & \text { Inlet water pressure, } \mathrm{Pa} \\ A_{t} & \begin{array}{l}\text { Total surface area of finned } \\ \text { tubes, } \mathrm{m}^{2}\end{array} & P_{\text {out }} & \text { Outlet water pressure, } \mathrm{Pa} \\ a_{a} & \begin{array}{l}\text { Total air flow frontal area, } \mathrm{m}^{2} \\ a_{w}\end{array} & R_{\text {cond }} & \begin{array}{l}\text { Total tube wall conduction } \\ \text { resistance, } \mathrm{K} / \mathrm{W}\end{array} \\ & \text { Total water flow area, } \mathrm{m}^{2} & R_{f}^{\prime \prime} & \text { Fouling factor }, \mathrm{m}^{2} . \mathrm{K} / \mathrm{W}\end{array}$

Journal of Engineering Sciences, Assiut University, Faculty of Engineering, Vol. 41, No. 3, May, 2013, E-mail address: jes@aun.edu.eg 
A. Kahoul et al., Performance study of generator air coolers for the hydro-power plant at Aswan high dam, pp. 1054 - 1077

\begin{tabular}{|c|c|c|c|}
\hline$C$ & Heat capacity ratio & $S_{L}$ & $\begin{array}{l}\text { Longitudinal pitch of tube bank, } \\
\mathrm{m}\end{array}$ \\
\hline$C_{\max }$ & $\begin{array}{l}\text { Maximum heat capacity rate, } \\
\text { W/K }\end{array}$ & $S_{T}$ & Transverse pitch of tube bank, m \\
\hline$C_{\text {min }}$ & $\begin{array}{l}\text { Minimum heat capacity rate, } \\
\text { W/K }\end{array}$ & $T_{c}$ & Cold air temperature, ${ }^{\circ} \mathrm{C}, \mathrm{K}$ \\
\hline$c_{p a}$ & Specific heat of air, J/kg.K & $T_{h}$ & Hot air temperature, ${ }^{\circ} \mathrm{C}, \mathrm{K}$ \\
\hline$c_{p w}$ & Specific heat of water, J/kg.K & $T_{w, i n}$ & Inlet water temperature, ${ }^{\circ} \mathrm{C}, \mathrm{K}$ \\
\hline$d_{i}$ & Inner diameter of the tube, $\mathrm{m}$ & $T_{w, \text { out }}$ & Outlet water temperature, ${ }^{\circ} \mathrm{C}, \mathrm{K}$ \\
\hline$d_{o}$ & Outer diameter of the tube, $\mathrm{m}$ & $t_{f}$ & Fin thickness, $\mathrm{m}$ \\
\hline$h_{i}$ & $\begin{array}{l}\text { Inner heat transfer coefficientat } \\
\text { at } A_{i}, W / m^{2} \cdot K\end{array}$ & $U_{C}$ & $\begin{array}{l}\text { Overall clean heat transfer } \\
\text { coefficient, } \mathrm{W} / \mathrm{m}^{2} . \mathrm{K}\end{array}$ \\
\hline$h_{o}$ & $\begin{array}{l}\text { Outer heat transfer coefficient } \\
\text { at } A_{o}, W / m^{2} . K\end{array}$ & $U_{D}$ & $\begin{array}{l}\text { Overall dirt heat transfer } \\
\text { coefficient, } \mathrm{W} / \mathrm{m}^{2} . \mathrm{K}\end{array}$ \\
\hline$h_{t}$ & $\begin{array}{l}\text { average value of the outer heat } \\
\text { transfer coefficient for finned } \\
\text { tube surfaces, } \mathrm{W} / \mathrm{m}^{2} . \mathrm{K}\end{array}$ & & \\
\hline$L_{f}$ & Fin length, m & \multicolumn{2}{|c|}{ Greek Symbols } \\
\hline$L_{t}$ & Tube bundle length, $\mathrm{m}$ & $(-\Delta P)$ & Water pressure drop, $\mathrm{Pa}$ \\
\hline$n \& x_{a}$ & Mass flow rate of air, $\mathrm{kg} / \mathrm{s}$ & $\Delta T_{m}$ & $\begin{array}{l}\text { Mean air/water temperature } \\
\text { difference, } C\end{array}$ \\
\hline$n \mathbb{K}_{w}$ & Mass flow rate of water, $\mathrm{kg} / \mathrm{s}$ & $\left(-\delta T_{a}\right)$ & Air temperature drop, $\mathrm{C}$ \\
\hline$N$ & Number of transfer units (NTU) & $\varepsilon$ & Cooler effectiveness \\
\hline$N_{f}$ & $\begin{array}{l}\text { Number of fins per meter of } \\
\text { tube length, } \mathrm{m}^{-1}\end{array}$ & $\eta_{o}$ & $\begin{array}{l}\text { Overall surface efficiency of the } \\
\text { finned tubes }\end{array}$ \\
\hline
\end{tabular}

\section{References}

[1] B. Liddle, A. Tucker, I. Huntsman, M. Manders, and C. McDonald, "Redesigning the rotor fan blades to improve the cooling of Roxburgh's hydro-generators," $14^{\text {th }}$ Australasian Fluid Mechanics Conference, Adelaide University, Adelaide, Australia, December 2001, pp. 465468.

[2] M. Fujita, Y. Kabata, and T. Takumasu, "Air-cooled large turbine generator with multiplepitched ventilation ducts,” Proc. IEEE Int. Conf. Electr. Mach. Drives, May 2005, no. 15, pp. 910-917.

[3] P. Moradnia, V. Chernoray, and H. Nilsson, "Experimental and numerical investigation of the cooling air flow in an electric generator," $8{ }^{\text {th }}$ International Conference on Heat Transfer, Fluid Mechanics and Thermodynamics, 11-13 July 2011.

[4] E. A. Hartono, "Experimental study of air flow in a hydro power generator model: design, construction, and measurements," Master Thesis, Fluid Dynamics Division, Applied Mechanics Department, Chalmers University, Göteborg, Sweden, 2011.

[5] P. Moradnia, "CFD of air flow in hydro power generators," Thesis for the degree of Licentiate of Engineering in Thermo and Fluid Dynamics, Fluid Dynamics Division, Applied Mechanics Department, Chalmers University, Göteborg, Sweden, 2010.

Journal of Engineering Sciences, Assiut University, Faculty of Engineering, Vol. 41, No. 3, May,

2013,E-mail address: jes@aun.edu.eg 
A. Kahoul et al., Performance study of generator air coolers for the hydro-power plant at Aswan high dam, pp. 1054 - 1077

[6] Y. A. Gogus and O. E. Ataer, "Effect of fins on transient behavior of cross-flow air-liquid heat exchangers," International Refrigeration and Air Conditioning Conference, Paper 67, 1988.

[7] C. Taylor, "Measurement of finned-tube heat exchanger performance," Master Thesis, Mechanical Engineering Department, Georgia Institute of Technology, Georgia, December 2004.

[8] O. Guömundsson, "Detection of fouling in heat exchangers," Master Thesis, Mechanical Engineering Department, University of Iceland, Iceland, 2008.

[9] M. Thirumarimurugan, T. Kannadasan and E. Ramasamy, "Performance analysis of shell and tube heat exchanger using miscible system,” Am. J. Applied Sci., 5, 2008, pp. 548-552.

[10] M. Thirumarimurugan, T. Kannadasan and E. Ramasamy, "Simulation studies on a cross flow plate fin heat exchanger," Am. J. Applied Sci., 5, 2008, pp. 1318-1321.

[11] MESA Associates, Inc. and OAK Ridge National Laboratory, "Best Practice Catalog: Generator," 2011.

[12] R. K. Shah and D. P. Sekulić, "Fundamentals of Heat Exchanger Design," Wiley, NY, first ed., 2003.

[13] F. P. Incropera and D. P. Dewitt, "Introduction to Heat Transfer," Wiley, NY, third ed., 1992.

[14] Ernst U. Schlünder, Editor-in-chief, "Heat Exchanger Design Handbook," Vol.2, Hemisphere Publishing Corporation, 1983.

[15] E. M. Smith, "Advances in Thermal Design of Heat Exchangers," Wiley, NY, first ed., 2005.

\section{دراسة أداء مبردات هواء المولد الكهربى لمحطة القدرة الهيدروليكية بسد أسوان العالى}

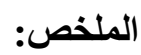

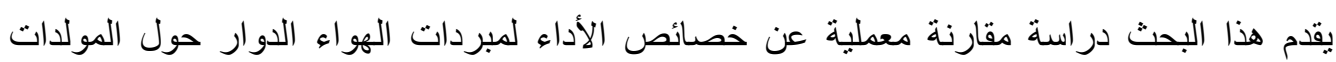

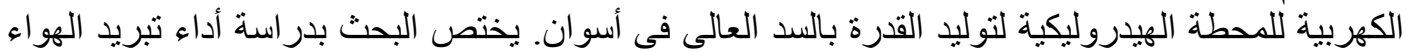

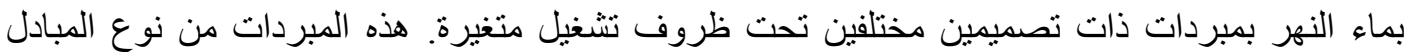

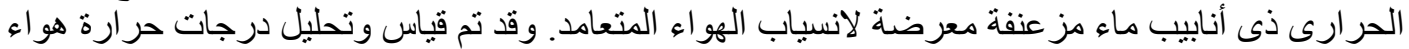

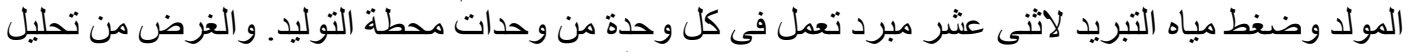

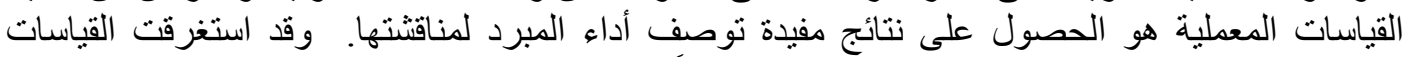

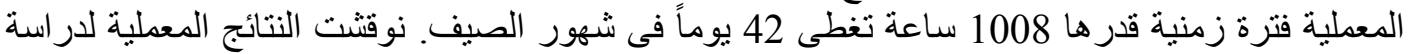

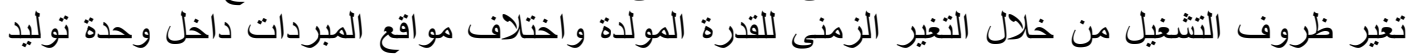

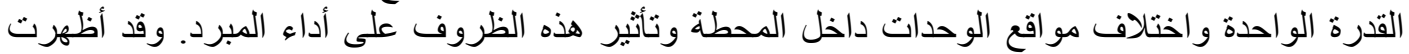

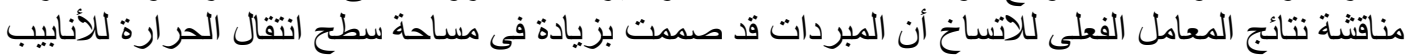

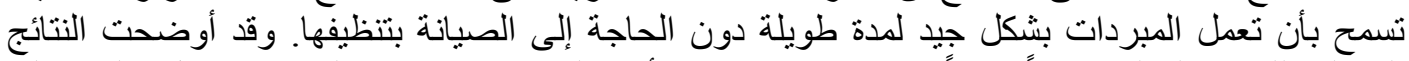

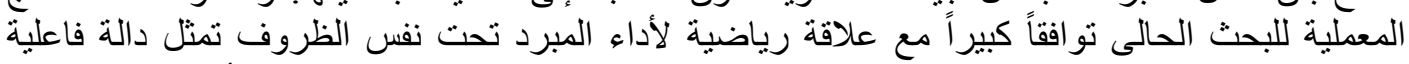

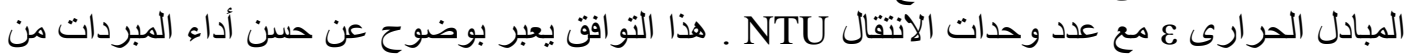

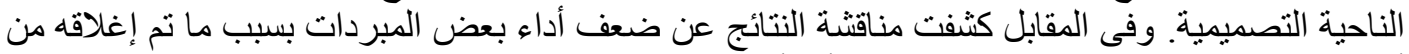

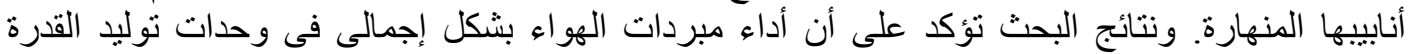

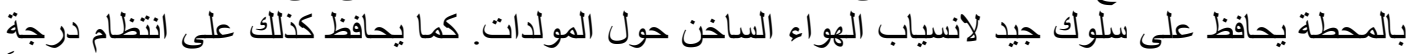

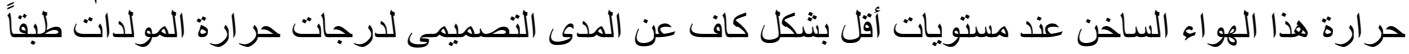

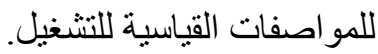

Journal of Engineering Sciences, Assiut University, Faculty of Engineering, Vol. 41, No. 3, May, 2013,E-mail address: jes@aun.edu.eg 